PATIENT PAGE

Section Editors

David C. Spencer, MD

Steven Karceski, MD

James F. Burke, MD

Roger L. Albin, MD

\title{
Do neurologists make a difference in Parkinson disease care?
}

HOW WAS THE STUDY PERFORMED? Willis et al. ${ }^{1}$ reviewed Medicare data to explore 2 questions. First, what characteristics determine whether a patient with Parkinson disease (PD) sees a neurologist? Second, are patients who see a neurologist likely to live longer than patients who do not see a neurologist? The Medicare data for this study data came from insurance claims. When a doctor sees a patient, he or she provides some basic information on forms sent to Medicare as reasons for payment, such as the diagnosis being treated. This type of data is powerful due to the large number of patients with these data. However, insurance claim-based data sources lack detailed information, so reaching definite conclusions is difficult. For example, an insurance claim just records that a patient has a diagnosis of $\mathrm{PD}$, but does not record symptoms, how long he or she has had the disease, or how severe the symptoms are.

WHAT DID THE STUDY FIND? Almost one-third of patients with PD in the study never visited a neurologist. The authors found that certain groups of patients were less likely to see a neurologist. For example, African Americans and women were less likely to see a neurologist than white men. This effect could not be explained by differences in other factors such as income or education. This difference might be important because the authors also found that patients who saw a neurologist lived longer. Patients who saw a neurologist were also less likely to end up in a nursing home than those who did not.

WHAT DO THE STUDY FINDINGS MEAN FOR PATIENTS WITH PD? These findings suggest the importance of neurologist care for patients with PD. However, it is too early to make decisions on the impact of neurologist care on PD outcomes from this study alone. Observational studies based on insurance claims have drawbacks and conclusions should be made with care. Many factors that the authors were not able to measure could explain the relationship between neurologist care and apparently better outcomes in PD. The authors, for example, were unable to measure the severity of PD in this population. If patients seen by neurologists had less severe PD than patients not seen by neurologists, the apparently better outcomes in neurologist-treated patients could be a reflection of disease severity instead of better care.

While these findings are new and point to new ways to improve the care of patients with $\mathrm{PD}$, further research to confirm and explain these findings is needed.

\section{REFERENCE}

1. Willis AW, Schootman M, Evanoff BA, Perlmutter JS, Racette BA. Neurologist care in Parkinson disease: a utilization, outcomes, and survival study. Neurology 2011;77: $851-857$. 
PATIENT PAGE

Section Editors

David C. Spencer, MD

Steven Karceski, MD

\section{About Parkinson disease}

WHAT IS PARKINSON DISEASE? Parkinson disease (PD) is a common disease in older adults. In $\mathrm{PD}$, specific brain cells slowly die. Brain cells that communicate with each other using a specific chemical, dopamine, are particularly susceptible to death in patients with PD. Loss of these brain cells leads to the most common symptoms of PD, including slowness of movements and tremor. Most treatments available for PD increase levels of brain dopamine to help dopamine-containing cells communicate better.

HOW IS PD TREATED? Several medications are available to increase dopamine-based brain cell communication in PD. The oldest and best studied of the medications, L-dopa or levodopa, is a chemical that is changed into dopamine in the brain. Newer medications help dopaminecontaining cells communicate better either by directly activating them (for example, ropinirole and pramipexole) or by reducing the breakdown of dopamine (selegiline, rasagiline, entacapone). Medications are effective at reducing the symptoms of
PD, but do not slow down the process of brain cell death.

Most patients with PD are treated by primary care physicians or neurologists. Primary care physicians are broadly trained to diagnose and treat a wide variety of diseases. Neurologists are more specifically trained in the diagnosis and treatment of diseases of the nervous system, such as PD. Neurologists typically receive more training in managing $\mathrm{PD}$, including in the use of $\mathrm{PD}$ medications, than primary care physicians. There is little prior evidence, however, that seeing a specific type of doctor affects patients' outcomes in PD.

\section{FOR MORE INFORMATION}

AAN Patients and Caregivers site: American Academy of Neurology

http://patients.aan.com

American Parkinson Disease Association

http://www.apdaparkinson.org

National Parkinson Foundation

http://www.parkinson.org

WE MOVE (Worldwide Education \& Awareness for Movement Disorders)

http://www.wemove.org

\section{Neurology Now - Another AAN Resource for Patients and Caregivers}

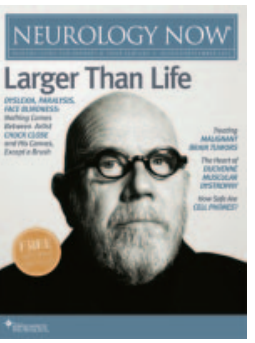

Neurology Now, an official publication of the American Academy of Neurology (AAN), provides patients and caregivers with credible, up-to-the-minute, balanced coverage of the latest advances in neurology research and treatment. The articles help people manage and make informed decisions about treatment options for a wide-range of neurologic disorders.

Neurology Now is available free of charge to individuals with a neurologic disorder, their caregivers, and family members/friends residing in the U.S only. To subscribe, go to neurologynow.com and click on the "Subscribe Now" tab. 


\section{Neurology}

\section{Do neurologists make a difference in Parkinson disease care? \\ James F. Burke and Roger L. Albin \\ Neurology 2011;77; e52-e523 \\ DOI 10.1212/WNL.0b013e31822f48fb}

\section{This information is current as of August 29, 2011}

\section{Updated Information \& Services}

References

Citations

Subspecialty Collections

Permissions \& Licensing

Reprints including high resolution figures, can be found at: http://n.neurology.org/content/77/9/e52.full

This article cites 1 articles, 1 of which you can access for free at: http://n.neurology.org/content/77/9/e52.full\#ref-list-1

This article has been cited by 1 HighWire-hosted articles: http://n.neurology.org/content/77/9/e52.full\#\#otherarticles

This article, along with others on similar topics, appears in the following collection(s):

\section{All Movement Disorders}

http://n.neurology.org/cgi/collection/all_movement_disorders

Parkinson's disease/Parkinsonism

http://n.neurology.org/cgi/collection/parkinsons_disease_parkinsonism

Information about reproducing this article in parts (figures,tables) or in its entirety can be found online at:

http://www.neurology.org/about/about_the_journal\#permissions

Information about ordering reprints can be found online:

http://n.neurology.org/subscribers/advertise

Neurology ${ }^{\circledR}$ is the official journal of the American Academy of Neurology. Published continuously since 1951, it is now a weekly with 48 issues per year. Copyright Copyright $@ 2011$ by AAN Enterprises, Inc.. All rights reserved. Print ISSN: 0028-3878. Online ISSN: 1526-632X.

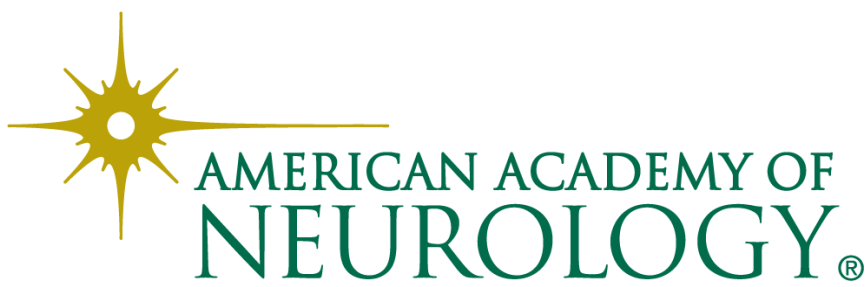

